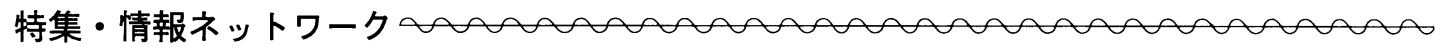

\title{
情報システムを利用した地球環境保全
}

\author{
古 田 眞一郎 *
}

\section{1. 環境に有益な情報システム}

地球の生命力が実のところ意外にも脆いものである ことに気づき始めた今, 遅まきながらも私たち一人ひ とりが環境問題に関心を示し始めたことは，それ自体 が極めて重要なことと思います.

しかし，それぞれが思い思いの方法で地球をクリ一 ンアップしていくには，この地球は余りにも大きすぎ て効率的とはいえません，そこで考えられるのが，情 報システムを活用した地球環境保全なのです、

これまでにも，情報システムはモータリゼーション を通信に移行したり，文書情報を電子化することによっ て，環境破壊の回避あるいは資源消費の極少化に貢献 してきた訳ですが，今後さらに考えを押し進めて「情 報システムは環境を破壊しない=無害」という消極的 な立場から，「情報システムは環境を保全する＝有益」 という積極的な立場へとテーゼの変更を図ることが強 く求められてきます.

そこで, 情報システムが地球環境問題にどのように 貢献しているのか，事例を交えながらその現状をご紹 介するとともに，今後の情報システム技術の発展の可 能性を念頭において, 将来の環境情報システムの動向 について考えてみたいと思います。

\section{2. 衛星利用による環境モニタリング}

89年 6 月に, 政府は「地球環境保全に関する関係閣 僚会議」を開き，地球環境保全の基盤づくりのための 各種試作の指針を示し, 広域的な大気, 海洋, 生体系 等の観測と全地球的な環境監視の分野で積極的に貢献 していくことで基本的合意を行っていますが，地球規 模の環境モニタリングを行うためには，衛星等を利用 して行う「リモート・センシング=地球探査」が，広

*日本電信電話(㑣) N T T 関西支社地域開発推進部 Shinichiro FURUTA
範囲な観測が可能で，しかも即時にデータが得られる ため極めて効果的な方法といえます。

この衛星を利用したリモート・センシングは，72年 にアメリカで地球資源衛星「L A N D S A T」が打ち 上げられて以来, 気象観測衛星「NOAA」(米), 高 性能陸域観測衛星「S P OT」(仏) 等, 多くの衛星 が大気污染, 水質污濁, さらにはオン゙ン層の破壊状況 等に関する貴重なデー夕を提供してきています。

一方，日本であ 87 年 2 月に海洋観測衛星 1 号「屯む 1 号」が，ついで90年 2 月に同 1 号-b「むも 1 号$\mathrm{b} 」$ が打ち上げられ，海洋面および温度を中心とした 海洋現象の観測等に活躍しています，そして，国内に おけるリモート・センシング受信基地は，現在のとこ ろ宇宙開発事業団地球観測センター（埼玉県鳩山町） と，東海大学宇宙情報センター（熊本県益城町）の 2 基地があり, 衛星から送られてきた電波を受信し, 記 録・再生, デー夕処理等を行っています，

実際にリモート・センシングを利用したシステムと しては，(財)国際湖沼環境委員会が衛星（L A N D S A T）から送信される水面の光や電磁波のデー夕によっ て, 湖沼の浮遊物質量や植物プランクトン量, 水温を 調查する「湖沼環境情報システム」の構築に，90年 4 月から着手しています.

また，野生動物保護におけるリモート・センシング の有用性を示す事例として，日本野鳥の会が渡り鳥の 首や背中に, NT T等が開発した小型の発信機を取り 付け,この電波を衛星（NOA A) が受信して, 渡り 鳥の位置を割り出すことに成功しています．このシス テムによって, 野生動物の生息地や行動範囲を把握す ることができ, 生息領域が狭域化しつつある野生動物 のために，どの地域をどのように保護したらよいかの 判断資料を獲得することができます。

郵政省では，89年 9 月から「地球環境保全における 電波利用と情報通信に関する愁親会」を開催してきて 
おり，その中でリモート・センシング・システムの確 立に向け，次のような提言をしています.

(1) 熱帯降雨の観測を効率よく行うための地球環境電 磁波センサー（熱帯降雨観測衛星搭載用降雨レーダー 等）およびデー夕処理に関する技術開発の推進.

(2) オン゙ン層の破壊, 地球温暖化問題解明のための地 球環境リモート・センシングによる観測体制の整備.

(3) 太陽・地球間の環境の解明之, 太陽活動等の強化 のための「宇宙天気予報システム」の研究開発.

より高度なリモート・センシングの実現に向けて, 各国の次期衛星の開発が着々と進められている中で, わが国では世界各国の資源探査や環境污染の監視等を 目的とする, 地球資源衛星 1 号「E P S - 1」の打ち 上げが予定されていますが，この衛星には今までの光 学センサーに代わって高性能レーダーが搭載され, 地 球に発射したマイクロ波の反射波で, 地形や地上の状 態を精密に識別することが可能となっています.

さらに，94年度には地球観測プラットホーム技術衛 星「ADEOS」が打ち上げられる予定であり，地球 環境のグローバルな変化の監視について国際的な貢献 を図るとともに，「屯も1号」「ER S - 1」の地球観 測技術のバージョンアップを図る予定となっています．

これから90年代後半にかけて, 日・米・欧が相次い でこのような地球観測プラットホーム衛星を打ち上げ る計画となっていますが, 将来においては, そこから 得られたデー夕をネットワーク化し，地球環境の予測 モデル作りに役立つようなシステム構築が求められて います。

\section{3. 地球環境のためのデータベース}

環境問題への取り組みが多様化・重層化する中で, リモート・センシングを通して得られたモニタリング デー夕や, 国土数値デー夕, 地球社会経済デー夕等, 環境問題に関わるデー夕も膨大な量になってきていま す.これらデー夕の数值を最大限に発揮するためには, 情報の共有化を図るとともに，情報の知得活動の容易 化が必要であり, データベースの充実が課題となって くるでしょう。

環境庁の国立環境研究所環境情報センターでは, 環 境行政や環境研究において必要とされる環境数值情報 を広く収集し, 多方面の利用に適するようなデータベー スを構築しています，そのデータベースには，全国 都道府県がテレメータ等を通して収集した数值情報 （大気環境デー夕, 水質環境デー夕等）や, 研究報告
論文など環境に関する文献情報が収録されています。 そして, 環境情報センターには, 地球環境に関するデ一 夕を収集し，世界各国に提供する国連環境計画（U N E P ) の, 国際環境情報源照会システム（I N F O T ERRA）におけるわが国の代表機関（ナショナルフォー カスポイント) として, I NFOTERRAに登録さ れている約6,500の情報源の情報提供む行っています.

また，今後ますます複合化されるであろう環境問題 に対して, 多元的アプローチを試みるために, 環境庁 のほか通産省, 気像庁など 5 つの省庁が, 降水量や才 ゾンの濃度, 海面・地表の温度などのデー夕を集め, 気象変動のモデル作りや予測のための「地球環境総合 データベース」を構築するための検討を開始しました。

このように地球環境に関して世界の行政機関, 研究 所などで構築されるデータベースの数は, 数百にのぼ るとみられますが,

(1) データの電子化が充分でない

(2) デー夕検索方法が難しい

(3) 異機種コンピュータ間のオンライン利用ができな い

(4) データの種類や所在を示すディレクトリデータベー スが末整備 などの問題を残しています.

そこで, 今後データべースの充実を図るためには, 紙や磁気テープ，フロッピーディスクなぞ非オンライ ンで提供されているデータをオンラインに移行したり， 検索支援システムや異機種コンピュータ接続技術等の 開発を進めるなど, 欲しい情報に手軽にアクセスでき る環境整備が必要となってきます。

\section{4. 地球環境のための情報ネットワーク}

いまや全地球的規模で取り組むべき環境問題に関し て, 私達がそれぞれに有する情報や知識の価值を相乗 的に高めるためには, 国際的に地球環境に関わる情報 を相互に利用・交換できる情報通信ネットワークの活 用が必要不可欠になってくるでしょう.

環境庁では, 国立環境研究所と全国の研究所, 自治 体とをパソコン通信でネットした「環境情報ネットワー ク（E I - NE T)」を構築し, 前述の環境情報セン ターに蓄積されたデー夕を提供したり, 電子掲示板や 電子メールを通じて地球環境について意見・情報の交 換を行うことができるサービスを 91 年 3 月からスター トさせました。

同様に，行政機関が主体となったネットワークとし 


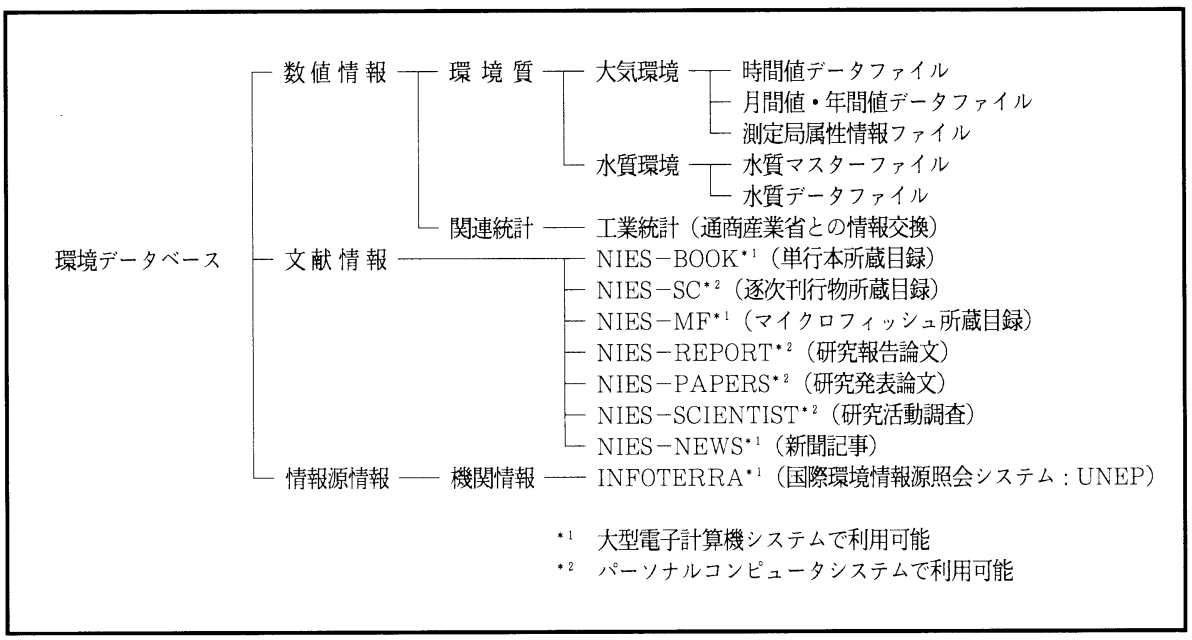

(国立環境研究所環境情報センター資料)

図ー1 国立環境研究所環境情報センターのデータベース

て, 放射線や湖沼の水質状況に関する環境情報や文献 情報の提供を行うパソコン通信ネットも稼㗢している ほか，民間企業においても環境問題を専門に扱うパソ コン通信ネットが登場したり，市民グループの中にお いてもリサイクル活動にこのパソコン通信を活用する ケースが出てきています。

コンピュータを結んだネットワークは，比較的コス トが安いうえに, 即時検索, リアルタイムの情報交換 が可能であるため，今後ますます裙野を広げていくむ のと思われますが，一方では，

(1) 伝送スピードが荤い

(2) 文字・数值以外の情報を伝送するための環境が未 整備

(3) 異機種ネットワークが困難 などの欠点が指摘されています.

郵政省では，「地球環境情報ネットワークに関する 調查研究会」を開き，今後の技術動向を踏まえ，これ ら問題点をクリアしていく意向であるが，そのポイン 卜を纏めると次のことが言えます。

(1) まず，伝送速度については，I S D NあるいはA T M技術を根幹とする広帯域 I S D N , さらには衛 星通信技術等の開発により, 高速の伝送が実現され ます。

(2) また，現行のネットワークが文字・数值情報を中 心として構成せざるを得ないという問題については, 音声認識, 高解像度ディスプレイ，画像压縮技術の 発展に伴って, 音声情報やカラ一画像情報, 動画情 報などマルチメディアの情報通信が提供されます。
(3) 異機種コンピュー夕の相互接続についても, 現在 開発が進められていますＯＳＩ（開放型システム間 相互接続）の標準化によって，マルチベン夕環境下 においてす相互接続が可能となります.

同研究会では，こうした技術課題を克服したうえで， 96年度を目処に将来の望ましい「地球環境情報通信ネッ トワーク」のモデルシステムを構築する考えでいます．

\section{5 .より高度な環境情報システムのために}

このように，環境情報の効率的な「収集」「管理」 「利用」に，情報システムは幅広く取り込まれつつあ りますが，これまでの環境情報システムと呼ばれてい るものには，文字・数值情報が主体となっていたため， かなり難解な物であったため，いわば尃門家のための あのであった，と言えます。

そこで，これを市民参加型の開かれたネットワーク とするために，専門的知識がなくてもイメージ的に理 解できるような画像情報のニーズが今後ますます高ま るむのと思われます，その意味で，コンピュータ・グ ラフィックスの活用は，時々刻々と変化する環境情報 をリアルな形で再現できるうえ, 地球環境の解析や予 測などに極めて有効なものになるでしょう。ささらに， 人間の有する直感のような非定型的情報を認識, 処理 する「四次元コンピュー夕」などの開発により, 今後 はより高度なシミュレーションが可能となってくるむ のと予想されます。

「世界的にネットワーク化された動画像端末装置を 前に，モデルシミュレーションを繰り返しながら相互 


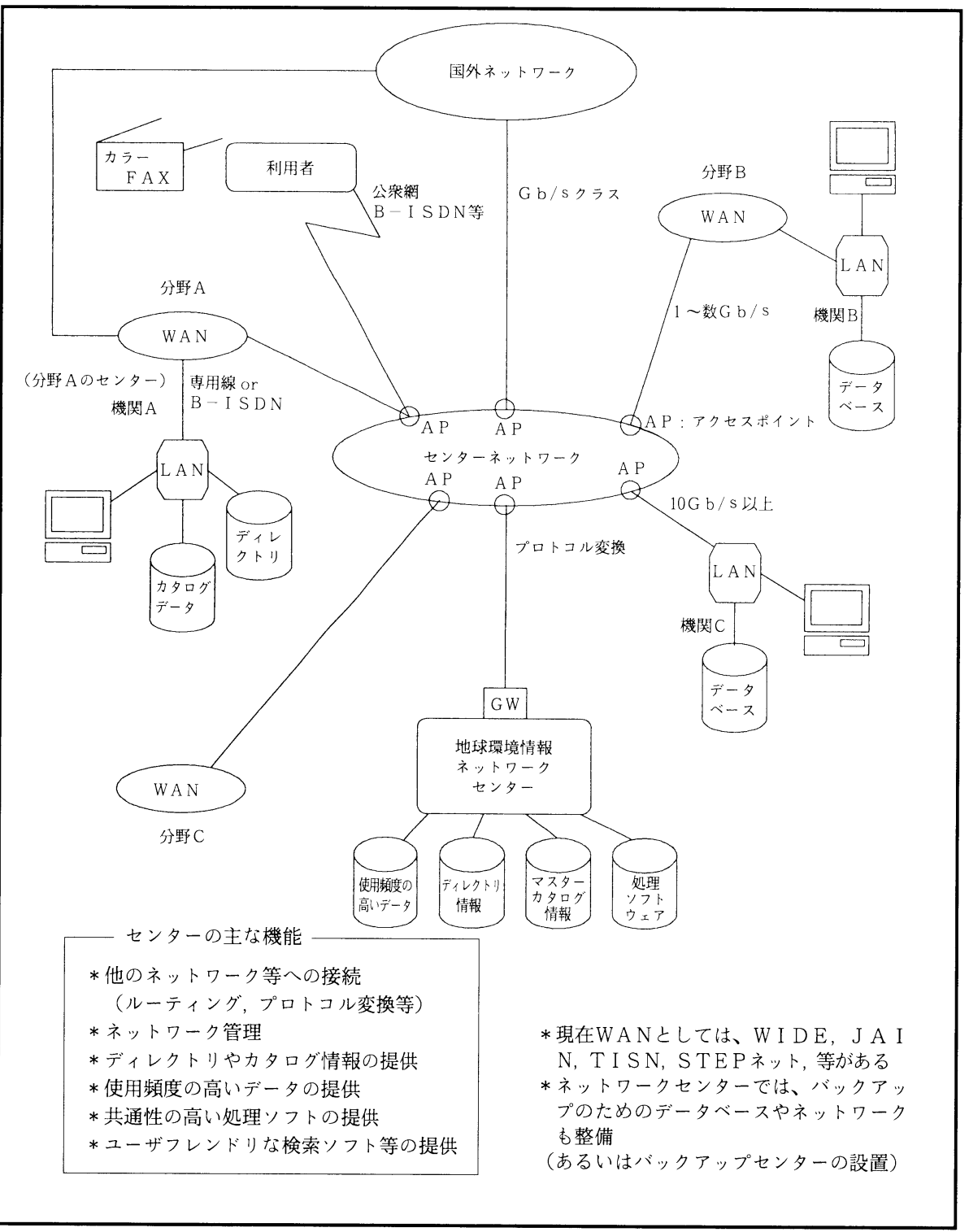

(郵政省「地球環境保全環境情報通信ネットワークの開発に関する調查研究会報告書」)

図ー2 地球環境情報通信ネットワークシステムモデル案

の意見を交換しあい地球環境保全のための最適解を導 く」，そんな支援システムが，これからの環境情報シ ステムのコンセプトとなってくるでしょう。

しかし言うまでもなく重要なことは, この環境情報 システムによる情報を単に知識として止めておくので はなく，そこから得られた英知を官民一体となって， 地球的規模で環境保全のための行動にフィードバック するプロセスを実践することにあります。そのために は，限られた環境資源の南北間配分，あるいは技術移 転や資金援助などの政策的課題がなお解決を待ってい

\section{ます。}

いま，地球環境保全に向けた機運は46億年という地 球の歴史の中で未だかつてなかったほどに熱気を帯び てきていますが,これを一過性的なブームに終わらせ てしまってはなりません.

$\lceil$ Only One Earth」一かけがえのない地球を, 瑠 璃色の輝きを失わないまま元の綺麗な形で次代の継承 者に引き継ぐために, 人類は何処まで理性のある生き 物であるのでしょうか. 